\title{
LO TRÁGICOY LO CÓMICO MEZCLADO EN LAS PIEZAS AMATORIAS DE CALDERÓN ${ }^{1}$
}

\author{
Felipe B. Pedraza Jiménez \\ Instituto Almagro de Teatro Clásico \\ Facultad de Letras \\ Universidad de Castilla-La Mancha \\ 13071 Ciudad Real \\ España \\ Felipe.Pedraza@uclm.es \\ Universidad de Castilla-La Mancha
}

\section{«LO TRÁGICO Y LO CÓMICO MEZCLADO»: TEMA Y LEMA}

El verso 174 del Arte nuevo de hacer comedias («lo trágico y lo cómico mezclado») ha servido en los últimos tiempos como motivo, excusa o trampolín desde el que los estudiosos se han lanzado a la exploración de algunos aspectos fundamentales de la dramaturgia áurea. Figura como parte del título en un puñado de interesantes ensayos ${ }^{2}$; todo un congreso ha tratado de indagar en la presencia de esta mezcla desde la Antigüedad a nuestros días ${ }^{3}$, y ha servido para rotular una recopilación de artículos

${ }^{1}$ Este trabajo es fruto de la investigación que viene desarrollando el Instituto Almagro de teatro clásico. Se incluye dentro de los proyectos FFI2011-25040 (I+D) y CSD2009-00033 (Consolíder), aprobados por la secretaría de estado de Ciencia e Innovación.

${ }^{2}$ Ver Arellano, 2011, pp. 223-248; Antonucci, 2011; Pontón, 2011; Romanos, 2010, y Trambaioli, 2013.

${ }^{3}$ Ver Torres y Ferry (ed.), 2013. 
sobre el teatro áureo ${ }^{4}$. Es lógico que así sea, ya que sintetiza una de las características fundamentales y más controvertidas de la comedia española.

\section{LAS DOCTRINAS CLÁSICAS (“ARCAICAS») SOBRE LO CÓMICO}

Las teorías sobre lo cómico tienen una larga genealogía crítica que arranca de la antigua Grecia (Platón se ocupa de este asunto en Filebo), continúa en la Roma clásica (Cicerón nos habla del sentimiento y los mecanismos de lo cómico en De oratore, LVIII) y sigue en los tiempos modernos en la pluma de filósofos de extraordinario renombre: Hobbes, Kant, Bergson, Freud, entre muchos otros no menos célebres ${ }^{5}$.

La comicidad de que trata la tradición clásica a la que me he referido en primer lugar se basa en la superioridad moral, social, fisica e intelectual del espectador sobre los personajes. Ya Platón en su diálogo Filebo (con frecuencia subtitulado Del placer) definió «lo ridículo» como un vicio, una forma del mal que nace del desconocimiento de uno mismo, de las falsas ilusiones respecto a sus bienes, a su cuerpo y a su alma ${ }^{6}$. Los objetos cómicos están vistos desde el aire por el espectador. Por eso el discípulo y albacea filosófico de Sócrates añade una condición: que "sean débiles e incapaces de tomar venganza», porque, si no, nos encontraríamos ante la tragedia: el odio, la crueldad, el resentimiento. Es la idea repetida por Suárez de Figueroa en El pasajero:

De aquí se infiere (escribe un gramático) ser error poner en la fábula hechos de principales, por no poder inducir risa, pues forzosamente ha de proceder de hombres humildes. Los sucesos, porfias y contiendas de estos mueven contento en los oyentes; no así en las reyertas de nobles. Si un príncipe es burlado, luego se agravia y ofende; la ofensa pide venganza; la venganza causa alborotos y fines desastrados, con que se viene a entrar en la juridición del trágico ${ }^{7}$.

\footnotetext{
${ }^{4}$ Ver Profeti, 2014.

${ }^{5}$ Ver el resumen que ofrece, en relación a la comedia española, Profeti, 1992.

${ }^{6}$ Platón, Filebo (48-49), pp. 88-89.

${ }^{7}$ Suárez de Figueroa, El pasajero, p. 78.
} 


\section{LA MEZCLA TONAL EN EL TEATRO MODERNO}

Entre los varios ingredientes de lo cómico que manejan estos filósofos de lo risible, en los tiempos modernos hemos privilegiado fundamentalmente el tono. Es decir, hemos vinculado la concepción de lo cómico al sentimiento que engendra en nosotros, de risa, alegría o euforia; y la de lo trágico, a la tristeza, el dolor, la pena o la desazón. De ahí la importancia que damos a la inclusión o no de violencias graves en la acción dramática, de situaciones dolorosas o placenteras, y del final feliz o desdichado con que se remata la trama.

Estas contrapuestas perspectivas se dan, se han dado y se seguirán dando siempre fundidas en la realidad, y esa fusión se ha trasmitido a su representación artística en la mayor parte de las culturas. Como recordó Rodríguez Adrados, la mezcla de lo trágico y lo cómico está en los más remotos orígenes del teatro:

La vida humana, como el proceso de la Naturaleza, comporta muerte y triunfo, dolor y alegría; todo ello se expresaba al tiempo, mediante la yuxtaposición de rituales diferentes y la ambivalencia de otros. Fuera de Grecia, el teatro nacido de los rituales agrarios continúa combinando lo trágico y lo cómico: solo Grecia ha creado la gran escisión, que luego vuelve a desaparecer en un Lope de Vega o un Shakespeare ${ }^{8}$.

Convendría matizar esta última afirmación. El teatro moderno en ningún caso vuelve a la yuxtaposición o a la ambigüedad de los ritos ancestrales: no los tiene como modelo. El canon de lo trágico y lo cómico para el drama barroco se sustenta - yo diría que de manera exclusivaen la tradición griega y latina, la única - me parece- que gravita, de forma directa o indirecta, sobre la creación del teatro moderno occidental. Así, al menos, lo manifiesta clara y específicamente Lope de Vega:

Lo trágico y lo cómico mezclado, y Terencio con Séneca, aunque sea como otro Minotauro de Pasife, harán grave una parte, otra ridícula; que aquesta variedad deleita mucho. Buen ejemplo nos da naturaleza, que por tal variedad tiene belleza9.

\footnotetext{
${ }^{8}$ Rodríguez Adrados, 1972, p. 481.

${ }^{9}$ Lope de Vega, Arte nuevo de hacer comedias, vv. 174-180.
} 
De estos versos han deducido algunos críticos que en la comedia española se da una informe amalgama que no permite distinguir variantes genéricas y en la que las perspectivas cómicas y trágicas se pueden confundir en la representación o la lectura, o por decirlo con mayor exactitud, están confundidas desde su misma raíz.

Esta tesis parece — solo parece- estar avalada por estos versos del Arte nuevo y por algunas expresiones que encontramos en los tratadistas contemporáneos. Quizá la más reiteradamente citada es la frase de Ricardo de Turia en su Apologético de las comedias españolas: «ninguna comedia de cuantas se representan en España lo es, sino tragicomedia, que es un mixto formado de lo cómico y lo trágico.... ${ }^{10}$.

Algo muy parecido encontramos en Cigarrales de Toledo de Tirso de Molina: «¿qué mucho que la comedia, a imitación de entrambas cosas, varíe las leyes de sus antepasados y injiera industriosamente lo trágico con lo cómico, sacando una mezcla apacible de estos dos encontrados poemas...?» ${ }^{11}$.

\section{LAS VARIEDADES DRAMÁTICAS ÁUREAS}

Estas palabras, que siempre se citan aisladas, fuera de su contexto, chocan con la evidencia escénica de que, durante cuatro siglos, los espectadores han reaccionado de manera diametralmente opuesta ante el repertorio de las obras de Lope, Calderón y otros ingenios áureos: respondiendo con risa en unos casos y con lágrimas en otros.

Chocan también con el criterio de muchos contemporáneos que señalan la existencia de variantes notables entre las piezas dramáticas. Así, por ejemplo, Juan de la Cueva en su Ejemplar poético: «La comedia es retrato del gracioso / y risueño Demócrito, y figura / la tragedia de Heráclito lloroso» ${ }^{12}$.

Podría alegarse que en 1606 el Ejemplar poético conserva resabios de las doctrinas clasicistas. Sin embargo, no parece ser ese el caso de Carlos Boyl, que unos años antes, en 1600, en el romance $A$ un licenciado que deseaba hacer comedias, distingue claramente tres géneros dramáticos:

\footnotetext{
${ }^{10}$ En Norte de la poesía española, fols. preliminares, s. n.

${ }^{11}$ Tirso de Molina, Cigarrales de Toledo, p. 127.

${ }^{12}$ Juan de la Cueva, Ejemplar poético, epístola III, vv. 667-669.
} 
La comedia es una traza

que, desde que se comienza

hasta el fin, todo es amores, todo gusto, todo fiestas.

La tragicomedia es

un principio cuya tela

(aunque para en alegrías)

en mortal desdicha empieza ${ }^{13}$.

La tragedia es todo Marte, todo muertes, todo guerras, que por eso a las desgracias las suelen llamar tragedias ${ }^{14}$.

\section{LA TONALIDAD FRENTE A OTROS COMPONENTES DEL DRAMA}

A mi entender, el problema crítico radica en que palabras como las de Ricardo de Turia, Tirso de Molina y otras del propio Lope se han interpretado desde la perspectiva dominante en tiempos posteriores, que privilegia o vincula en exclusiva la distinción genérica a la tonalidad (grave, trascendente y dolorosa en la tragedia, o risueña, intrascendente y ligera en la comedia). Pero a la altura de las primeras décadas del siglo XVII, cuando se escribían estos textos, todos sus emisores tenían muy presentes otros elementos que pesaban tanto o más en la separación de los géneros teatrales.

Ya el Pinciano, en la epístola nona de la Filosofía antigua poética (1596), enfrentó la posición de Fadrique, que reducía la antítesis entre comedia y tragedia a las diferencias que hemos llamado tonales, y

${ }^{13}$ Arellano (2011, p. 224) ha señalado que esta definición es, «cuando menos, curiosa, y describe exactamente lo opuesto de lo que sucede en alguna pieza que el mismo Lope califica de tragicomedia, como es El caballero de Olmedo». Probablemente Boyl (A un licenciado que deseaba hacer comedias), aunque no lo exprese con total exactitud, estaba pensando en otra variante, mucho más numerosa, de comedia española en que la acción va desde el desorden y la violencia del nudo dramático, al orden, el equilibrio y la justicia poética del final feliz. Olvidó señalar el poeta valenciano que, casi siempre, el planteamiento presenta una cierta felicidad que la soberbia, la ira, la lujuria o la torpe inadvertencia del antagonista rompe: no acostumbran estas tragicomedias a empezar «en mortal desdicha», sino que la introducen poco después de arrancar la acción. Las piezas que reproducen este esquema y que Lope subtitula tragicomedias son numerosas: Peribáñez, Las paces de los reyes, Fuenteovejuna, El bastardo Mudarra, El mejor alcalde, el rey...

${ }^{14}$ Carlos Boyl, $A$ un licenciado que deseaba hacer comedias, vv. 9-20. 
las teorías de Hugo, que apostaba por un amplio manojo de marcas genéricas:

Es la primera de las diferencias (que entre la tragedia y comedia se ponen) que la tragedia ha de tener personas graves, y la comedia, comunes. Y es la segunda que la tragedia tiene grandes temores llenos de peligro, y la comedia, no. La tercera, la tragedia tiene tristes y lamentables fines; la comedia, no. La cuarta, en la tragedia, quietos principios y turbados fines; la comedia, al contrario. La quinta, que en la tragedia se enseña la vida que se debe huir, y en la comedia, la que se debe seguir. La sexta, que la tragedia se funda en historia, y la comedia es toda fábula, de manera que ni aun el nombre es lícito poner de persona alguna, como ya se dijo antes. La séptima, que la tragedia quiere y demanda estilo alto, y la comedia, bajo.Y aun otras muchas más que no me acuerdo ponen los escritores, y ansí me admiro que vos, con sola esta palabra «por medio de pasatiempo y risa", queráis diferenciar a la comedia de la tragedia ${ }^{15}$.

A este cúmulo de características se podrían añadir otras varias ${ }^{16}$ : por ejemplo, como señaló Wardropper, la soltería de los protagonistas, propia de la comedia; y el matrimonio, que marca la tragedia ${ }^{17}$.

$\mathrm{Si}$ atendemos al conjunto de estas marcas, como hacían los teorizantes de principios del siglo XVII, y no solo a la impresión global que causan en el espectador, hay que concluir, casi sin reservas, que todas las comedias españolas son «un mixto formado de lo cómico y lo trágico", es decir, contienen rasgos peculiares o exclusivos de la comedia, y otros propios de la tragedia. Personajes de altísimo copete (reyes, duques, señores absolutos) van a ser protagonistas de enredos risibles; y labradores y plebeyos se van a calzar el coturno trágico. El estilo humilde y el sublime alternan en los parlamentos dramáticos. Ocasionalmente, la acción cómica se sitúa en un pasado histórico en el que pululan, con sus propios nombres, personas que figuran en las crónicas y anales, a veces vinculadas a un sino trágico y violento, como ocurre en La niña de plata de Lope de Vega, uno de cuyos agonistas es el rey Pedro I de Castilla.

En todas las comedias nuevas (sean cómicas o trágicas, amatorias o historiales, imaginadas o sucedidas) ha de darse la yuxtaposición de la

\footnotetext{
${ }^{15}$ Pinciano, Filosofía antigua poética, p. 383.

${ }^{16}$ Ver Pedraza, 2007, pp. 161-186.

${ }^{17}$ Wardropper, 1976, p. 722.
} 
risa y el patetismo. Ha de haber lances y situaciones que se sustentan en la anestesia sentimental que nos lleva a ver la situación desde una perspectiva distante y distinta de la que sienten determinados personajes. En todas las comedias españolas aparece — de forma más o menos nítida según las etapas de su evolución- una figura específica encargada de provocar la reacción cómica: el gracioso.

Es cierto, como analizó Arellano ${ }^{18}$ a propósito de Calderón, que la comicidad puede quedar en los márgenes de la acción trágica y llegar a invertir su función tradicional:

sin abandonar las yuxtaposiciones de comicidad convencional obedientes a las expectativas del público, explora otros modos de inserción del gracioso en un juego admirable en el que la presencia extravagante e impertinente de los agentes cómicos, y el vaciamiento de su función, llega a convertirlos paradójicamente en agentes trágicos, invirtiendo su papel para expresar el cierre absoluto de unas tramas sin apertura posible a la liberación cómica ${ }^{19}$.

Así es, sin duda; pero, aun en estos casos, el contrapunto humorístico - por más ocasional y marginal que sea- no deja de gravitar sobre el universo trágico. Incluso puede llegar a poner una nota sarcástica y teñir de absurdo nihilismo el universo grave y luctuoso. Este fenómeno se puede observar muy claramente (porque resulta más abultado y chocante) en las parejas de graciosos que intervienen en dos tragedias de la órbita calderoniana como son El Caín de Cataluña y Progne y Filomena de Rojas Zorrilla ${ }^{20}$. Su papel no incide en la acción central, pero pone una nota chirriante en el conjunto dramático. Por eso, le molestaban tanto a don Alberto Lista: «Hay muchas escenas episódicas y dos bufones que pudieran ir a otra parte a decir sus gracias» ${ }^{21}$.

Llanos López, basándose en las ideas sicocríticas de Mauron ${ }^{22}$, señaló que en Calderón (en realidad en toda la comedia española) se dan dos fenómenos distintos: por un lado, una comicidad menor (sería más adecuado llamarla ocasional) a través del chiste, de la breve píldora jocosa que se introduce en cualquier acción más o menos grave, más o menos

${ }^{18}$ Arellano, 2006, pp. 33-53

${ }^{19}$ Arellano, 2006, p. 53.

${ }^{20}$ Ver Pedraza, 2007, p. 67.

${ }^{21}$ Lista, Lecciones de literatura española explicadas en el Ateneo Científico, Literario $y$ Artístico, tomo II, p. 286.

${ }^{22}$ Ver Llanos, 2002 y 2005, y Mauron, 1997. 
ligera; y, por otro, lo que llama el arte cómico, que impregna el conjunto de la obra y lleva al espectador a la euforia (la eutrapelia de que habló Orejudo ${ }^{23}$ ). El contraste entre una comedia de capa y espada (Casa con dos puertas...) y una tragedia (El médico de su honra), que Wardropper había tratado de identificar y confundir ${ }^{24}$, le sirven para señalar que

en la comedia seria se persigue en momentos muy puntuales la risa, en el caso de la comedia cómica se busca mantener a lo largo de la pieza y como elemento definidor de su construcción, la eufori $a^{25}$.

Todo esto es verdad y nos sirve para separar un género de otro; pero no encontraremos comedia española (sea globalmente trágica o cómica) que no cuente con el patetismo simpático que conmueve al espectador; en la que no aparezcan unas figuras, los amantes, cuyos diálogos y soliloquios han de mover "con extremo a quien escucha»; y en la que no encontremos parlamentos y escenas que piden la plena identificación del actor con los personajes de modo «que se transforme todo el recitante, / y con mudarse a sí, mude al oyente» ${ }^{26}$.

Lo cómico tal y como lo concebían Platón o Cicerón, es decir, la representación de situaciones y personas que resultan ridículas por sus taras, defectos, actitudes grotescas..., que las sitúan social, fisica, moral e intelectualmente por debajo del espectador, no constituye, en términos generales, el sostén de la comedia española. Solo en algunas etapas y en ciertas variantes encontramos el predominio de esta concepción de la comicidad. Es el caso de los primeros pasos de la comedia urbana, en la que aún pesan mucho los modelos terencianos, italianos y el género celestinesco ${ }^{27}$. También pudieran entrar en este saco la comedia de figurón o lo que he llamado la "comedia cínica»: Abrir el ojo de Rojas Zorrilla, por buen ejemplo ${ }^{28}$.Y aun en estos casos, con matices de importancia.

Lope tenía muy claro que ese tipo de humor que se sostiene en la superioridad del espectador sobre los personajes había quedado relegado al entremés:

\footnotetext{
${ }^{23}$ Ver Orejudo, 1996.

${ }^{24}$ Ver Wardropper, 1976.

${ }^{25}$ Llanos, 2002, p. 1059.

${ }^{26}$ Lope de Vega, Arte nuevo de hacer comedias, vv. 275-276.

27 Ver Arellano, 1999, pp. 77-106.

${ }^{28}$ Ver Pedraza, 2007, pp. 27-29, y Brioso, 2013.
} 
de donde se ha quedado la costumbre de llamar entremeses las comedias antiguas, donde está en su fuerza el arte, siendo una acción y entre plebeya gente, porque entremés de rey jamás se ha visto ${ }^{29}$.

En cambio, la comedia, aunque su tonalidad sea risueña, su final feliz y sus situaciones pacíficas o de una violencia limitada o nula (por ejemplo, muchas de las comedias urbanas de la década de 1610), contendrá siempre rasgos de emoción y patetismo, de dignidad y respeto de los agonistas, que la acercan a lo que los clasicistas consideraban el ámbito propio de lo trágico. En este sentido deben entenderse las palabras de Ricardo de Turia:

$\mathrm{Y}$ asimismo, en aquel breve término de dos horas, [los espectadores] querrían ver [en la comedia] sucesos cómicos, trágicos y tragicómicos, dejando lo que es meramente cómico para argumento de los entremeses que se usan agora $^{30}$.

Por eso, la comedia española podía incorporar personajes de la más variada índole social: «Elijase el sujeto, y no se mire / — perdonen los preceptos - si es de reyes... $\|^{31}$.

Y por eso, Ricardo de Turia completaba su razonamiento con estas palabras:

es un mixto formado de lo cómico y lo trágico, tomando de este las personas graves, la acción grande, el terror y la conmiseración; y de aquel, el negocio particular, la risa y los donaires.Y nadie tenga por impropiedad esta mixtura, pues no repugna a la naturaleza y al arte poético que en una misma fábula concurran personas graves y humildes ${ }^{32}$.

Y Tirso redondeaba el suyo preguntándose qué razón puede oponerse a que la comedia española presente «una mezcla apacible de estos dos encontrados poemas [trágico y cómico] y que, participando de entram-

${ }^{29}$ Lope de Vega, Arte nuevo de hacer comedias, vv. 69-73.

${ }^{30}$ Ricardo de Turia, Apologético de las comedias españolas, fols. preliminares, s. n.

${ }^{31}$ Lope de Vega, Arte nuevo de hacer comedias, vv. 157-158.

${ }^{32}$ Ricardo de Turia, Apologético de las comedias españolas, fols. preliminares, s. n. 
bos, introduzga ya personas graves, como la una, y ya jocosas y ridículas, como la otra $»^{33}$.

\section{LA COMICIDAD COMPLEJA DEL TEATRO MODERNO}

La propuesta encierra una nueva comicidad más compleja que la registrada por los tratadistas clásicos y sus secuaces. En otra ocasión, relacioné este nuevo concepto de lo cómico con la ruptura de las estrechas leyes del decoro, cuya idea de lo verosímil convertía la ficción dramática o narrativa en el reino de lo previsible, de lo esperable, de la estratificación estamental de los comportamientos ${ }^{34}$. Señalé en aquel escrito las contradicciones de Cervantes a este respecto. En el cap. 48 del Quijote de 1605 , lo vemos metido a preceptista dramático, a través de las voces del canónigo de Toledo y del cura del lugar de la Mancha, defendiendo las leyes que predeterminan el comportamiento de los personajes: «¿Y qué mayor [disparate] que pintarnos un viejo valiente y un mozo cobarde, un lacayo rectórico, un paje consejero, un rey ganapán y una princesa fregona?» ${ }^{35}$.

Sin embargo, en la misma novela asistimos al tránsito entre la comicidad arcaica (o clásica y clasicista, si lo prefieren) y el humor moderno: don Quijote empieza siendo una figura cómicamente caracterizada por la turpitudo et deformitas (loco, desconocedor de su propia realidad y de la ajena, enteco, larguirucho, cómicamente vapuleado en multitud de ocasiones); pero va convirtiéndose en una criatura compleja (sin dejar de provocar la risa y la sonrisa), hasta el extremo de que don Diego de Miranda, paradigma de la sensatez en el relato cervantino, concluye «que era un cuerdo loco y un loco que tiraba a cuerdo» ${ }^{36}$.

Creo que, en el fondo, la comedia española recorre el mismo camino. De los personajes moralmente despreciables de los primeros tiempos (rufianes, alcahuetas, hermanitas del buen pecar, soldados fanfarrones), pasamos a criaturas nobles, respetables, casi siempre pertenecientes a los grupos privilegiados, incluso a la alta nobleza, pero que no por eso dejan de provocar la risa y la sonrisa del espectador, es decir, caen en la esfera

\footnotetext{
${ }^{33}$ Tirso de Molina, Cigarrales de Toledo, p. 127.

${ }^{34}$ Ver Pedraza, 2006, pp. 204-206.

${ }^{35}$ Cervantes, Don Quijote de la Mancha, I parte, cap. 48, p. 483.

${ }^{36}$ Cervantes, Don Quijote de la Mancha, II parte, cap. 17, p. 640.
} 
de lo cómico de acuerdo con la concepción que vincula la división genérica a la tonalidad.

\section{CALDERÓN Y SUS PIEZAS AMATORIAS}

Calderón, sin duda, es el más feliz heredero de esta compleja concepción dramática. En sus piezas amatorias, según la denominación empleada por Bances Candamo (de ingenio para Suárez de Figueroa; morales, virtuales o pensadas para Caramuel), encontramos (con contadas salvedades que han sido objeto de numerosas reflexiones críticas en los últimos tiempos ${ }^{37}$ ) una tonalidad marcadamente risueña, que provoca la carcajada, induce a la euforia y se dirige hacia el final feliz. Es decir, en mi concepto y en el de los espectadores de todos los tiempos (no así en el de un conocido sector de la crítica de los siglos xx y xxI), pertenecen a lo que, por lo común, identificamos con lo cómico, lo intrascendente, lo jocoso y distendido. Difieren, en su esencia, de las piezas historiales (sucedidas, de acuerdo con la denominación de Caramuel), en las que el tono dominante es angustioso, sombrío, y en las que aparecen violencias graves e irreparables.

A pesar de estos contrastes, los enredos amatorios de Calderón, como toda la comedia española, no pertenecen al mundo de la comicidad descrita por Platón, Cicerón y los humanistas que fijaron y difundieron sus doctrinas. Sus personajes son respetables, dignos, nobles (aunque pertenezcan, o porque pertenecen a la clase media urbana); su lenguaje es elevado, con una voluntaria y relevante carga retórica; las situaciones por las que atraviesan nos llevan a identificarnos con sus cuitas y angustias: no son bobos de entremés o maridos consentidos, o lisiados y gangosos, o mezquinos rufianes... No entran tampoco en el universo disparatado, absurdo, incongruente de la mojiganga o la comedia burlesca, ni utilizan el lenguaje inarticulado, del que se ocupó, al menos en un par de ocasiones, Arellano ${ }^{38}$.

Al no participar de estas marcas infamantes y degradadoras, la acción dramática que protagonizan configura un universo que se separa

${ }^{37}$ El interés se ha centrado, no sin razón, en el valor y significado moral y dramático de No hay cosa como callar. Véase un excelente estado de la cuestión en el artículo de Escudero (2013), cuyas conclusiones, sin embargo, podríamos discutir.

38 Ver Arellano, 1999, p. 271, y 2010. 
de manera clara e indudable de la comicidad arcaica y se adentra, en el concepto de sus creadores, en el ámbito de la tragicomedia.

Podría ejemplificarse con cualquiera de las comedias calderonianas. Como el espacio es limitado, me centraré en una obra maestra preterida sin motivo ni razón: Los empeños de un acaso.

Se trata de una pieza publicada en la Sexta parte (póstuma, 1683; preparada por Juan de Vera Tasis). Su autoría ha sido discutida: Profeti abogó por la atribución a Juan Pérez de Montalbán, a cuyo nombre se imprimió un par de veces con el título de Los empeños que se ofrecen (rótulo expresamente repudiado por Calderón, quizá sin percatarse de que se trata del mismo texto que Los empeños de un acaso $)^{39}$. Recientemente, Alfonso Barrios ha defendido la autoría calderoniana, tesis que me parece acertada, aunque no me acaben de convencer los argumentos que esgrime el estudioso (sobre todo, la presencia del ambiente madrileño, común, como bien se sabe, a la mayor parte de las comedias urbanas) ${ }^{40}$. En todo caso, para lo que en este momento pretendo comentar, es indiferente que sea o no de nuestro autor. Se trata de una ejemplar comedia de capa y espada, que contiene los ingredientes característicos de la generación calderoniana. Podemos considerarla paradigmática de una peculiar variedad para la que, en mis estudios sobre Rojas Zorilla, he propuesto el remoquete de "comedia pundonorosa» ${ }^{41}$.

\section{RESOLUCIONES TRÁGICAS, ABOLENGO ARISTOCRÁTICO, ALTA RETÓRICA}

La acción arranca con unos versos que expresan la drástica resolución de los personajes, propia de un lance trágico en que, sin vacilar, se pone la vida al tablero:

FÉLIX $\quad$ O he de matar o morir, o quien sois he de saber.

Diego Pues mirad cómo ha de ser; que yo no lo he de decir.

FÉLIX Con vuestra muerte o mi muerte, que es el último remedio

\footnotetext{
${ }^{39}$ Ver Profeti, 1983.

${ }^{40}$ Ver Alfonso Barrios, 2014.

41 Ver Pedraza, 2007, pp. 16-23.
} 
de mis celos; que otro medio no permiten... ${ }^{42}$

No son bravatas propias de los fanfarrones matasietes en la tradición del Centurio celestinesco, cómicamente desmentidas por el miedo subyacente. El espectador no se distancia ni pone en entredicho cuanto afirman los personajes. Al menos, no lo vive con la regocijada y despectiva convicción de que mienten, fingen, representan ridículamente un papel que no les corresponde.

El lance constituye uno de esos ingredientes trágicos que, con harta frecuencia, fundamentan y vertebran la acción cómica en las obras de la generación calderoniana ${ }^{43}$. Quizá pensando en estos elementos, el moderno editor de Los empeños de un acaso tuvo que hacer equilibrios rayanos en la paradoja para definirla: «en ella se juega, de manera desenfadada, aunque no distentida, con las responsabilidades que, surgidas de situaciones casuales o azarosas, deben asumir los personajes nobles en la vida» ${ }^{4}$.

En efecto, los tres galanes que entran en esta danza de espadas, que se juegan la vida en más de una escena, pertenecen a familias nobiliarias. Al menos, eso nos hacen pensar (a nosotros y a los espectadores contemporáneos) sus nombres y apellidos: don Félix de Toledo, don Juan de Silva y don Diego de Lara.Y su comportamiento no va a desdecir esa alcurnia que sugieren sus patronímicos.

Todos los personajes de esa esfera aristocrática (mesoaristocrática, podríamos decir) se sentirán zarandeados por hondas congojas, y recurrirán a las estructuras retóricas propias de la dicción trágica.Véanse, si no, esta acumulación de paralelismos metafóricos para encerrar en palabras la angustia de don Diego:

Veré si con ella venzo este tropel de desdichas, este raudal de recelos, este piélago de penas, abismo de sentimientos,

42 Calderón, Los empeños de un acaso, p. 255.

${ }^{43}$ Ver Pedraza, 2007, pp. 31-49. Rodríguez Valle, 2013, ha repasado muchas de las comedias de Calderón en que se desenvainan las espadas (unas veces, en escena; otras, en relación).

${ }^{44}$ Viña Liste, 2010, p. XxxII. 
y para decirlo todo, esta avenida de celos... (p. 271)

Todo el discurso remata en una resolución que considera esta angustia del amante despechado un valor absoluto, al que está dispuesto a sacrificarlo todo: «que donde ellos son lo más, / todo lo demás es menos» (p. 271).

Frente a la comicidad carnavalesca que presenta el sentimiento del personaje como algo grotesco y despreciable, ningún espectador de Los empeños de un acaso deja de considerar digna y moralmente atendible la zozobra de don Diego. Se produce una reacción simpática frente a sus temores y angustias, que responde a lo que el Pinciano estableció como rasgo propio de la tragedia, de acuerdo con una cita bien conocida por todos los especialistas: «la diferencia que hay de los temores trágicos a los cómicos es que aquestos se quedan en los mismos actores solos, y aquellos pasan de los representantes en los oyentes...» ${ }^{45}$.

\section{EL DRAMA PRIMAVERAL DE LA SOLTERÍA}

Pero tampoco se le oculta a este espectador conmovido por las cuitas del personaje, que la situación no cumple algunos de los preceptos trágicos. Uno de ellos parece fundamental: los agonistas son solteros, y en el horizonte de expectativas del receptor pesa la experiencia de que estas violencias son tentativas, ensayos adolescentes previos al encuentro de un acomodo satisfactorio en el entramado vital y social. La reina de luz, la divina esperanza, endulza las tensiones, a veces muy graves, casi letales, y pone en sordina el sentimiento trágico que expresan las palabras y los ademanes de los protagonistas.

Ya Northrop Frye señaló cómo el drama que hemos convenido en llamar comedia se perfila a los ojos del espectador como una acción optimista en que se materializa el esperanzador triunfo de la juventud ${ }^{46}$. Es el género primaveral y germinador ("The Mythos of Spring: Comedy»), cuyo protagonismo corresponde en exclusiva a los personajes que se encuentran en la radiante epifanía de su sexualidad.

El auditorio no se distancia incrédulo de los agonistas (como en el entremés o en la farsa). Al contrario, late a su ritmo, sufre y goza con

\footnotetext{
${ }^{45}$ Pinciano, Filosofía antigua poética, p. 385.

${ }^{46}$ Ver Frye, 1957, pp. 163-186.
} 
ellos, empuja con el corazón para que se cumplan sus deseos y desaparezcan sus tormentos; pero no puede dejar de teñir de esperanzado escepticismo esa sacudida emocional que le ha trasmitido el personaje.

Los caballeros, como vio Arellano, se convierten en agentes cómi$\cos ^{47}$, pero de una comicidad menos explícita que la arcaica, más compleja. Son cómicos, esencialmente, porque desconocen las circunstancias que los condicionan, y yerran al reaccionar frente a ellas. Manotean en el aire. Pero esta forma del ridículo (de lo que hace reír) no los convierte en inferiores a nosotros ni fisica ni moral ni social ni intelectualmente. Los protagonistas de este drama optimista no caen en el vicio de desconocer su propio ser y engañarse respecto a sus bienes, su cuerpo o su alma, como señalaba Platón en Filebo. En estos casos, la superioridad del espectador es meramente informativa y atañe solo a las circunstancias del enredo: tenemos más datos, podemos juzgar mejor los azares con que se ha tejido la maraña, y reírnos de los involuntarios e inevitables errores del personaje, que no queda rebajado a nuestros ojos, sino que engendra un sentimiento de identificación afectiva.Vivimos sus cuitas, pero sonreímos porque nuestro dominio de la situación dramática nos permite entender sus verdaderas dimensiones y dar alas a la esperanza donde el galán o la dama no ven más que la negrura de un destino aciago.

A veces, como ocurre en las escenas finales de Los empeños de un acaso, la confusión de los personajes se multiplica: don Diego está convencido de que la tapada que encuentra en casa de don Juan es su amada y desdeñosa Leonor, y a ella se dirige con palabras dolidas, despechadas y amorosas. Pero el espectador sabe que está hablando a su hermana Elvira: «Que me enamore mi hermano / es solo lo que me falta» (p. 337).

Don Félix, creyendo también que la tapada es Leonor, reprocha a don Juan que haya permitido que don Diego llegue hasta ella. Don Juan, para salvar a Elvira de que la descubra su hermano, la encomienda a don Félix, pero don Diego quiere acompañarla a todo trance, y Leonor, que está oculta en una sala contigua, siente celos y sale a deshacer esta transacción en el momento en que llega don Alonso, padre de Leonor, en busca de su hija...

A este equívoco múltiple — cuya comicidad es tan evidente en escena como imposible de sugerir en el discurso crítico- se ha llegado,

${ }^{47}$ Ver Arellano, 2011, pp. 185-222. 
como acostumbra a ocurrir en la comedia calderoniana, por medio de una cadena de lances tan sorprendentes como inevitables, en los que un exacerbado sentimiento del pundonor lleva a las criaturas escénicas a comportarse de forma tan lógica como incongruente y chocante con lo que el auditorio sabe que son sus deseos e intereses.

Si el espectador disfruta con los aprietos de damas y galanes, es porque intuye que todo se ha de resolver en la catástasis, en la distensión aliviadora del peligro. En el mismo momento en que se está produciendo el lance que la criatura dramática percibe, legítimamente, como trágico, el auditorio sabe que la violenta amenaza se va a resolver en nada.Y, natural y espontáneamente, no puede reprimir la carcajada o la sonrisa, ante los apuros infundados (sostenidos en vanas quimeras y datos falsos) que atenazan al conjunto de los personajes.

Con esto, la comedia calderoniana (también sus predecesores lopescos) creó un peculiar ámbito de comicidad, respetuoso con las damas, los galanes y los viejos honorables, solidario con ellos, incluso admirativo $^{48}$.

\section{LAS LECTURAS TRÁGICAS DE LOS ENREDOS CÓMICOS}

Esta corriente cordial entre las criaturas escénicas y el auditorio no implica que estemos ante una acción trágica, ni que se puedan leer en esa clave los lances del enredo, como ha pretendido una nutrida saga de estudiosos anglosajones bien conocida por todos los interesados en la crítica calderoniana: Leavitt, Wardropper, Wilson, Parker,Varey, Mujica...; a la que se han unido algunos españoles (Rey Hazas y Sevilla Arroyo, por ejemplo) y de otras nacionalidades. Arellano e Iglesias Feijoo nos han ofrecido sendos documentados estados de la cuestión, y han censurado, a ratos con justa indignación, estos planteamientos ${ }^{49}$.

\footnotetext{
${ }^{48}$ No me ocupo, por falta de tiempo y espacio (tan importante en el drama como en las conferencias y artículos), del contraste que se da entre la acción central de esta "comedia pundonorosa» y las escenas entremesiles protagonizadas por Hernando, el criado cobarde y desdichado de don Juan, al que un encolerizado don Félix da una puñalada tan terrible como injusta. Esta violencia, objetivamente grave, se resuelve de forma humorística gracias a la distancia, a la anestesia afectiva, a la falta de empatía, a la superioridad moral, física, social e intelectual que el espectador siente — con razón, sin razón o contra ella- respecto al personaje.

49 Ver Arellano, 1999, pp. 15-21, e Iglesias Feijoo, 1998, pp. 208-215.
} 
Los títulos mismos de algunos ensayos de la tradición crítica que comentamos inciden en la gravedad de los asuntos y en la actitud que sus exegetas vislumbran en las comedias amatorias de Calderón: "Calderon’s comedy and his serious sense of live», «El problema de la responsabilidad en la comedia de capa y espada de Calderón»... Esta postura alcanza prematuramente una de sus cimas en la pregunta retórica de Leavitt: «Did Calderón have a sense of humor?» ${ }^{50}$.

En mi concepto, toda su argumentación se sustenta en un mero prejuicio o, mejor, en dos juicios previos a la aportación de cualquier prueba o indicio racional: el carácter permanentemente grave, serio, trascendente del genial dramaturgo, y la nunca demostrada incompatibilidad entre la capacidad para la creación cómica y la trágica. De forma tan tosca como ingenua, lo expresó Wardropper en una de sus últimas incursiones en el tema: "How can this deadly serious writer provoke his audience to laugh at his scenic representations of funny men and women without betraying his sense of moral purpose?» [«¿Cómo puede este escritor mortalmente serio inducir al público a la risa en sus representaciones escénicas de hombres y mujeres alegres sin traicionar su sentido de propósito moral?»] $]^{51}$.

La pregunta retórica encadena una serie de supuestos sin aval objetivable alguno. El primero, que Calderón era un «escritor mortalmente serio». ¿Por qué?

El segundo supuesto que se presenta sin justificación alguna sostiene que los propósitos morales, más o menos explícitos en numerosos dramas calderonianos, son incompatibles con el humor y el regocijo en otros. El crítico anglosajón parece olvidar lo que ya apuntó Horacio en la oda VIII del libro II: «neque semper arcum / tendit Apollo» [«no tensa siempre el arco el dios Apolo"].Y también las indagaciones de Kant en su Crítica del juicio, que subraya el esencial desinterés de las creaciones estéticas de cualquier índole (incluidas las trágicas y trascendentes) ${ }^{52}$. La finalidad estética carece de objetivo, se cierra y acaba en sí misma, aunque a críticos y profesores nos resulte más fácil hablar de las resonancias sociales, políticas y morales de las obras literarias, que de su verdadera entraña estética lúdica y festiva.

\footnotetext{
${ }^{50}$ Ver Leavitt, 1950.

${ }^{51}$ Wardropper, 1986, p. 158.

${ }^{52}$ Ver Kant, Crítica del juicio, parte I \32, pp. 132-134, y \ 11, pp. 153-154.
} 
Al final, el propio Wardropper ha de reconocer que «a cada género dramático, a cada convención teatral le corresponde un distinto grado de responsabilidad», y que en las comedias de capa y espada «se examina únicamente el noviciado de la vida social y temporal ${ }^{53}$. Precisamente por eso, la perspectiva es cómica. Cuando se examinan cuestiones en que el poder letal de los agonistas es significativo y su responsabilidad mayor, entramos en el universo trágico.

A veces, no encontrando materia luctuosa en el conjunto de la acción que presentan las comedias de capa y espada, estos críticos sugieren - en una ensoñación que tiene mucho de quijotesca - que los fatales acontecimientos sobrevendrán una vez acabe la representación:

Hay, así, un matiz de desesperanza en la dicha de los amantes de las comedias de capa y espada, pues los amantes exultan en su alegría de vivir mientras los rodean omnipresentes espadas, constantes recordatorios de la muerte. En esta variedad de comedia se percibe un ritmo fadítico: del amor al honor, de la soltería a la vida de casado, del peligro salvado al peligro mortal en potencia que se cierne en el teatro sobre la mujer casada ${ }^{54}$.

En efecto, sobre la mujer casada se pueden cerner (o cernir, que de las dos formas puede decirse) infinidad de peligros; pero una de las diferencias esenciales entre la representación dramática y la vida es la peculiar prerrogativa de la primera, que acota con libertad un periodo de la existencia de los personajes. De lo contrario, no habría posible comedia, ya que toda vida humana acaba en la fatal tragedia de la aniquilación de los protagonistas, sin que hasta ahora se intuya excepción alguna a este principio.

Los que hemos asistido a tal cual representación de las comedias de Calderón y hemos leído alguna que otra, nos preguntamos qué han podido ver y leer nuestros admirados maestros anglosajones para hacerse semejantes preguntas y llegar a tales conclusiones.

Calderón — ¿quién lo duda? - es un inmenso poeta trágico, de planteamientos trascendentes, cargados de auténtica angustia; pero no está escrito en las estrellas que el dramaturgo que tiene esa capacidad para conmover y emocionar con el sentimiento agónico de la vida, no pueda también emocionar y conmover risueñamente con enredos

\footnotetext{
${ }^{53}$ Wardropper, 1976, p. 722.

${ }^{54}$ Wardropper, 1978, p. 227.
} 
cómicos. Entiéndase, globalmente cómicos, aunque en muchas ocasiones para provocar e intensificar la tensión humorística o alguna de sus manifestaciones, como la catástasis (esa ansiosa espera que se resuelve en nada, de acuerdo con la conocida expresión kantiana de la risa ${ }^{55}$ ), recurra a violencias graves que, sin dejar de serlo, en el preciso contexto dramático creado por el poeta, se quiebran y desaparecen en la distensión cómica.

Esta mixtura, y más que mixtura, emulsión artística en que se combinan de forma inseparable criaturas nobles, violencias graves, lenguaje elevado, altas sentencias y pensamientos, acendrado sentido del honor... con una perspectiva risueña, optimista y esperanzada no es un drama trágico, sino una manifestación de la moderna comicidad (más ambigua y compleja que la arcaica). Calderón y todos los dramaturgos que compartieron con él una misma afición y un mismo concepto del teatro sí tenían sentido del humor.

${ }^{55}$ Ver Kant, Crítica del juicio, parte I $₫ 54$, pp. 294-298. 


\section{BiBLIOGRAFÍA}

Antonucci, Fausta, "Lo trágico y lo cómico mezclado”", en Norme per lo spettacolo. Norme per lo spettatore. Teoria e prassi del teatro intorno all" "Arte nuevo». Seminario internazionale, ed. Giulia Poggi y Maria Grazia Profeti, Firenze, Alinea, 2011, pp. 99-118.

Arellano, Ignacio, Convención y recepción. Estudios sobre el teatro del Siglo de Oro, Madrid, Gredos, 1999.

Arellano, Ignacio, «La risa ausente: el gracioso en las tragedias de Calderón», en El escenario cósmico. Estudios sobre la comedia de Calderón, Madrid/Frankfurt, Universidad de Navarra / Iberoamericana / Vervuert, 2006, pp. 33-53.

Arellano, Ignacio, «Los disparates de Calderón», Anuario calderoniano, 3, 2010, pp. 37-66.

Arellano, Ignacio, El arte de hacer comedias. Estudios sobre teatro del Siglo de Oro, Madrid, Biblioteca Nueva, 2011.

Alfonso Barrios, Andreu, "Algunos rasgos característicos de Calderón en la comedia Los empeños de un acaso», Anuario calderoniano, 7, 2014, pp. 13-32.

Boy , Carlos, A un licenciado que deseaba hacer comedias. Romance, en Segunda parte de la silva de los versos y loas de Lisandro, Valencia, Miguel Prats, 1600, fols. s. n. Reproducido en Norte de la poesía española,Valencia, Felipe Mey, 1616, fols. preliminares, s. n.; y en Poetas dramáticos valencianos, ed. Eduardo Juliá Martínez, Madrid,Tipografia de la Revista de Archivos, 1929, pp. 627-629.

Brioso Santos, Héctor, "Que pecar en lo vedado / es el patrimonio de Eva": la comedia cínica del siglo XVII», en La desvergüenza en la comedia española. Actas de las XXXIV Jornadas de teatro clásico, ed. Felipe B. Pedraza Jiménez, Rafael González Cañal y Elena E. Marcello, Cuenca, Universidad de Castilla-La Mancha, 2013, pp. 145-178.

Calderón de la Barca, Pedro, Los empeños de un acaso, en Comedias VI. Sexta parte de comedias, ed. José María Viña Liste, Madrid, Biblioteca Castro, 2010, pp. 253-346.

Cervantes, Miguel de, Don Quijote de la Mancha, ed. Felipe B. Pedraza Jiménez y Milagros Rodríguez Cáceres, Madrid, Edaf, 2011.

Cueva, Juan de la, Ejemplar poético, precedido de El infamador y Los siete infantes de Lara, ed. Francisco A. de Icaza, Madrid, Espasa Calpe, 1973 [Sevilla, 1606].

Escudero, Juan Manuel, «Dislocaciones genéricas calderonianas. El llamativo caso de No hay cosa como callan, Anuario calderoniano, 6, 2013, pp. 75-93.

Frye, Northrop, Anatomy of Criticism. Four essays, Princeton, University of Princeton Press, 1957 [reimpresión, 1973].

IgLESIAS FeIJOO, Luis, «"Que hay mujeres tramoyeras”: la "matemática perfecta” de la comedia calderoniana”, en La comedia de enredo. Actas de las XX Jornadas de teatro clásico, ed. Felipe B. Pedraza y Rafael González Cañal, Almagro, Universidad de Castilla-La Mancha, 1998, pp. 201-236. 
Kant, Immanuel, Crítica del juicio, trad. Manuel García Morente, Madrid, Espasa Calpe, 2001 [Critik der Urtheilkraft, 1790].

LeavitT, Sturgis E., «Did Calderón have a sense of humor?», en Romance studies presented to William Morton Dey... on the ocasion of his seventieth birthday..., ed. Urban T. Holmes jr., Alfred G. Engstrom y Sturgis E. Leavitt, Chapel Hill, The University of North Carolina, 1950, pp. 119-121.

Lista y Aragón, Alberto, Lecciones de literatura española explicadas en el Ateneo Científico, Literario y Artístico, Madrid, José Repullés, 1853, $2^{\text {a }}$ ed., 2 tomos.

Llanos López, Rosana, «La comicidad en Calderón: de la risa a la euforia», en Calderón 2000. Homenaje a Kurt Reichenberger en su 80 cumpleaños. Congreso internacional IV Centenario del nacimiento de Calderón (2000), ed. Ignacio Arellano, Kassel, Reichenberger, 2002, tomo I, pp. 1046-1063.

Llanos López, Rosana, Teoría psicocrítica de la comedia. La comedia española del Siglo de Oro, Oviedo, Universidad de Oviedo, 2005.

Mauron, Charles, Psicocrítica del género cómico. Aristófanes, Plauto, Terencio, Molière, trad. María del Carmen Bobes Naves, Madrid,Arco, 1997 [Primera edición francesa: Paris, J. Corti, 1964].

Orejudo Utrilla, Antonio, "La eutrapelia en las comedias de capa y espada de Calderón», en En torno al teatro del Siglo de Oro. Actas de las Jornadas XII-XIII celebradas en Almería, ed. José Berbel, Heraclia Castellón, Antonio Orejudo y Antonio Serrano, Almería, Diputación Provincial de Almería, 1996, pp. 97-105.

Pedraza Jiménez, Felipe B., "Cervantes y Lope de Vega: historia de una enemistad» $y$ otros estudios cervantinos, Barcelona, Octaedro, 2006.

Pedraza Jiménez, Felipe B., Estudios sobre Rojas Zorrilla, Cuenca, Universidad de Castilla-La Mancha, 2007.

Pinciano, Alonso López, Filosofía antigua poética, ed. José Rico Verdú, Madrid, Biblioteca Castro, 1998.

Platón, Filebo, en Diálogos, VI, trad. M. ${ }^{a}$ Ángeles Durán y Francisco Lisi, Madrid, Gredos, 2000, pp. 7-122.

Pontón, Gonzalo, «Idea del teatro: lo trágico y lo cómico mezclados», en Historia de la literatura española, 8. Las ideas literarias (1214-2010), ed. José María Pozuelo Yvancos, Barcelona, Crítica, 2011, pp. 275-294.

Profeti, Maria Grazia, «Los empeños de un acaso de Pedro Calderón, Los empeños que se ofrecen de Juan Pérez de Montalbán», en Calderón. Actas del Congreso Internacional sobre Calderón y el teatro español del Siglo de Oro, ed. Luciano García Lorenzo, Madrid, Centro Supeior de Investigaciones Científicas, 1983, vol. I, pp. 249-254.

Profetr, Maria Grazia, "Código ideológico-social, medios y modos de la risa en la comedia áurea», en La vil quimera de este monstruo cómico, Kassel, Università degli Studi di Verona / Reichenberger, 1992, pp. 43-56.

Profeti, Maria Grazia, Lo trágico y lo cómico mezclado, ed. Agapita Jurado Santos, Kassel, Reichenberger, 2014. 
Rodríguez Adrados, Francisco, Fiesta, comedia y tragedia. Sobre los orígenes griegos del teatro, Barcelona, Planeta, 1972.

Rodríguez Valle, Nieves, "Capas terciadas y espadas desenvainadas en algunas comedias de Calderón", Anuario calderoniano, 6, 2013, pp. 211-228.

Romanos, Melchora, “"Lo trágico y lo cómico mezclado”. Sobre los modos en que el gusto por la comicidad muda los preceptos», en Cuatrocientos años del "Arte nuevo de hacer comedias» de Lope de Vega. XIV Congreso de la AITENSO, ed. Germán Vega García-Luengos y Héctor Urzaiz Tortajada, Valladolid, Universidad de Valladolid, 2010, pp. 111-127.

SuÁrez de Figueroa, Cristóbal, El pasajero, advertencias utilísimas a la vida humana, ed. Francisco Rodríguez Marín, Madrid, Renacimiento, 1913 [Primera ed.: Madrid, Luis Sánchez, 1617].

Tirso de Molina, Cigarrales de Toledo compuestos por el maestro Tirso de Molina, natural de Madrid, ed. Víctor Said Armesto, Madrid, Renacimiento, 1913 [Primera ed.: Madrid, 1624 (con aprobación de 1621)].

Torres, Milagros, y Ariane Ferry (ed.), Tragique et comique liés dans le théâtre, de l'Antiquité à nos jours (du texte à la mise en scène), Publications numériques di CÉRÉdl, 2013. Disponible en: <http://ceredi.labos.univ-rouen.fr/ public/?tragique-et-comique-lies-dans-le.html> [08/09/2016].

Trambaioli, Marcella, "Lo trágico y lo cómico mezclado en Il pastor Fido de Giovan Battista Guarini y sus reescrituras españolas», en Tragique et comique liés dans le théâtre, de l'Antiquité à nos jours (du texte à la mise en scène), ed. Milagros Torres y Ariane Ferry, Publications numériques di CÉRÉdl, 2013. Disponible en: <http://ceredi.labos.univ-rouen.fr/public/IMG/ pdf/TRAMBAIOLI.pdf $>$ [08/09/2016].

Turia, Ricardo de, Apologético de las comedias españolas, en Norte de la poesía española, ilustrado del sol de doce comedias..., Valencia, Felipe Mey, 1616, fols. preliminares, s. n.

Vega, Lope de, Arte nuevo de hacer comedias. Edición crítica. Fuentes y ecos latinos, ed. Felipe B. Pedraza Jiménez y Pedro Conde Parrado, Cuenca, Universidad de Castilla-La Mancha, 2016.

ViÑa Liste, José María, «Introducción», Comedias VI. Sexta parte de comedias de Pedro Calderón de la Barca, Madrid, Biblioteca Castro, 2010, pp. XxxI-XxxIV.

WARDROPPER, Bruce, «El problema de la responsabilidad en la comedia de capa y espada de Calderón», en Calderón y la crítica. Historia y antología, ed. Manuel Durán y Roberto González Echevarría, Madrid, Gredos, 1976, pp. 714-722.

Wardropper, Bruce, "La comedia española del Siglo de Oro», Teoría de la comedia, Barcelona, Ariel, 1978, pp. 180-235.

Wardropper, Bruce, "The numen in the genres of the Spanish Comedia», Iberorromaia, 23, 1986, pp. 156-166. 